Anglais de spécialité et milieux professionnels

\title{
Écrire la voile : les frontières mouvantes entre écrits spécialisés et littérature
}

Gwen Le Cor

\section{(2) OpenEdition}

\section{Journals}

Édition électronique

URL : http://journals.openedition.org/asp/1007

DOI : 10.4000/asp. 1007

ISBN : 978-2-8218-0396-1

ISSN : 2108-6354

Éditeur

Groupe d'étude et de recherche en anglais de spécialité

Édition imprimée

Date de publication : 1 mars 2004

Pagination : 47-56

ISSN : 1246-8185

Référence électronique

Gwen Le Cor, «Écrire la voile : les frontières mouvantes entre écrits spécialisés et littérature », ASp [En ligne], 43-44 | 2004, mis en ligne le 13 mars 2010, consulté le 24 avril 2019. URL : http:// journals.openedition.org/asp/1007; DOI : 10.4000/asp.1007

Ce document a été généré automatiquement le 24 avril 2019

Tous droits réservés 


\title{
Écrire la voile : les frontières mouvantes entre écrits spécialisés et littérature
}

\author{
Gwen Le Cor
}

\section{Introduction}

1 De l'espace clos du stade à l'espace virtuel du tube cathodique, le sport se regarde et se montre. Les retransmissions télévisuelles des matchs et la couverture médiatique extensive dont bénéficient les principaux «événements » sportifs ont fait entrer les athlètes et le sport dans les salons. Or, en faisant du sport un événement médiatique, les journalistes ont brouillé les limites entre culture populaire et culture sportive. Aguerri aux images sportives, le (télé)spectateur anglo-saxon dispose d'une représentation visuelle et mentale de la culture sportive. Se pose alors d'emblée la question de la spécificité de cette culture, et avec elle, celle des limites floues et mouvantes entre culture spécialisée et culture générale.

2 Si l'emprise des médias sur le sport témoigne d'un premier point de passage entre culture professionnelle et culture populaire, le discours sur le sport en sous-entend un second. Aux États-Unis, le sport se relate autant qu'il se montre. Preuve en est le nombre croissant des écrits sur le sport. Au côté des chroniques sportives dans des quotidiens nationaux et des magazines dédiés au sport en général (Sports Illustrated ${ }^{1}$ ), on assiste à un véritable foisonnement de magazines plus pointus consacrés à un sport particulier ou à un aspect spécifique d'un sport: Boating, Sail, Yachting World, Classic Boats, Wooden Boat, Waterski, WakeBoarding, Windsurfing, Surfing, KiteBoarding, Watercraft World pour ne mentionner que les principaux liés aux sports nautiques. Chaque nouveau sport (le « kiteboard»), chaque nouveau développement dans un sport (une nouvelle forme de skinautique) entraîne dans son sillage la parution d'un nouveau magazine (KiteBoarding et WakeBoarding respectivement). Si la presse fait la part belle au sport, les professionnels du 
sport prennent aussi la plume. Outre la publication de règlements et d'ouvrages explicitant ces règlements, on trouve des anthologies, des ouvrages techniques, des manuels sportifs pour néophytes ou encore des autobiographies. Cette diversité d'approches et de genres est complétée par des études sociologiques, des études philosophiques et des histoires. Enfin, c'est la fiction qui prend le sport comme objet, faisant du « roman de football » et « du « roman de baseball » des sous-genres à part entière ${ }^{2}$. Dans la mesure où le sport s'écrit de plus en plus en dehors du milieu sportif il serait réducteur d'envisager la « langue du sport » comme une donnée isolée.

"La langue spécialisée n'est rien d'autre que la langue 'en spécialité' », à savoir, "une langue en situation d'emploi professionnel » (Lerat 1995 : 40, 21). Aussi claire que puisse être la définition de Pierre Lerat, elle ne va pourtant pas de soi dans le domaine du sport. Le discours est en effet toujours second par rapport à la performance athlétique. Dans le cadre d'un sport individuel il se surajoute à la performance en forme de commentaire ou de description. En poussant cette logique à l'extrême, une épreuve de natation pourrait très bien se passer de toute parole. Réglée par un premier coup de sifflet qui invite les nageurs à monter sur les plots, elle démarre au coup de pistolet du "starter ", et s'achève par le temps inscrit sur le chronomètre. La « langue du sport » serait-elle alors celle des règlements et commentaires plus que celle des athlètes? Si la question semble évoquer le stéréotype de l'athlète illettré, elle souligne surtout la difficulté qui préside à toute étude de la langue du sport, à savoir celle de sa définition. Lorsqu'un écrivain emploie une terminologie sportive stricte, sa fiction est-elle moins du domaine de la langue de spécialité qu'un article destiné au grand public mais écrit par un sportif? Cette logique pourrait aisément aboutir à une vision réductrice de langue du sport, où seuls les ouvrages écrits par les sportifs et destinés aux sportifs (règlements, explications techniques...) constitueraient un champ d'étude légitime.

Catherine Resche envisage le passage de la langue générale à la langue spécialisée comme un «continuum» $(2001: 37)$. Cette notion de continuum est particulièrement utile dans le domaine du sport. Elle souligne les passages et emprunts entre plusieurs espaces linguistiques et nous invite à repenser la notion de langue spécialisée au travers de ses limites.

5 Il ne saurait alors s'agir ici d'opérer une classification des différents écrits par sous-genre, ni même de tenter une classification par degré de spécialisation, mais plutôt d'interroger l'espace d'intersection où la langue de spécialité rejoint la littérature.

\section{Sport et littérature}

6 Au premier abord, rien ne semble plus opposé que littérature et écrits spécialisés. Là où la littérature se veut création poétique et où le langage poétique se démarque de la fonction de communication du langage, les écrits spécialisés à l'inverse revendiquent leur fin comme " vecteur de connaissances spécialisées » (Lerat 1995 : 20). Si la distinction semble aller de soi, dans le domaine du sport, la limite est plus floue qu'il n'y paraît. Ainsi, lorsque Sports Illustrated propose une liste des 100 meilleurs livres sur le sport de tous les temps («Top 100 Sports Books of all Time » 16 décembre 2002), le magazine ne dissocie pas les écrits spécialisés de la fiction. Les apologies de légendes du baseball (Joe DiMaggio : The Hero's Life, 2000 ; Babe: The Legend Comes to Life, 1974) alternent ainsi avec les romans de baseball de Bernard Malamud (The Natural), de Philip Roth (The Great American Novel) ou de Robert Coover (The Universal Baseball Association, Inc.). La même logique opère pour la boxe 
et le football, puisque les romans de Norman Mailer (The Fight) et Don Delillo (End Zone) figurent au côté d'ouvrages écrits par des sportifs. La liste nie la séparation qu'écrivains

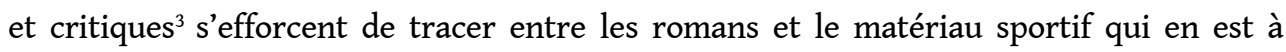
l'origine.

7 Interrogés sur leur œuvre, les écrivains en affirment en effet avant tout la fonction métaphorique. Coover souligne ainsi la fonction mythique du baseball («mythic quality $\left.{ }^{4} »\right)$ et Malamud décrit The Natural comme le récit d'un héros mythologique ( $I$ wrote The Natural as a tale of a mythological hero $\left.{ }^{5} »\right)$. Pourtant la liste de Sports Illustrated invite à une nouvelle lecture. Il n'est plus question de déplacement, de projection, ou de traduction, mais uniquement de sport.

De fait, le rapprochement inattendu qu'opèrent les journalistes nous incite à relire le texte spécialisé en nous attachant à ses limites. La voile offre un exemple particulièrement significatif à cet égard. Naviguer au large en solitaire ne nécessite ni écrit, ni discours. Écrire la voile c'est donc se situer d'emblée à la limite du texte spécialisé. Les éditeurs de recueils sur la voile ne s'y seront pas trompés. Classic Sailing Stories et The Sailing Book donnent ainsi à lire aussi bien les écrits de navigateurs, que ceux de journalistes, ou que ceux de Melville, Conrad ou London. Ils réunissent textes spécialisés, écrits journalistiques et littérature, suggérant une proximité textuelle que nous nous proposons d'examiner ici.

Afin d'envisager les limites du texte spécialisé, nous avons délibérément écarté les règlements de course et les instructions à l'intention des skippers, pour nous concentrer sur les écrits des navigateurs en solitaire. Du livre de bord, aux autobiographies nautiques en passant par les récits d'une étape ou d'une course autour du monde, le navigateurauteur donne à lire sa course. Se pose alors avec force la question de savoir ce qui différencie son texte du texte littéraire.

\section{Brouillage, passages}

10 Les quatrièmes de couverture apportent un premier élément de réponse. En définissant un ouvrage publié par un journaliste de "chef d'œuvre de la voile ${ }^{6}$ et en soulignant à l'inverse que l'autobiographie nautique de la navigatrice britannique Ellen MacArthur n'est pas un livre sur la voile ("This is not a sailing book» Nichols 2002), les critiques brouillent les limites entre écrits spécialisés et écrits journalistiques. Cette vision paradoxale est aussi celle que propose la navigatrice : «I have not tried to write a sailing book, nor a book about the Vendée Globe» (MacArthur 2003 : xix) 7 . Devant cette inversion, on serait tenté de conclure avec Walker Cronkite "The book is in the 'can't put down' category " (The Proving Ground).

11 De fait, la course au large a ceci de particulier par rapport à des sports comme le football ou le baseball qu'elle fait appel à plusieurs domaines d'activité. "A 'Jack of all trades'", voici comment se définit Ellen MacArthur. Outre son rôle de skipper, elle cumule les fonctions de voilier, d'électricien, d'ingénieur et de journaliste. Un métier à la croisée entre navigation et ingénierie où la mer est reléguée à une note en bas de page, telle est aussi la vision de Peter Nichols :

[Ellen MacArthur] becomes, with concentrated application and training, an engineer and technician who, alone at sea, in addition to famously climbing a mast (many times) unaided during stormy weather, can strip down and repair broken hydraulic gear, computer circuitry, and by intelligence and mechanical aptitude, 
overpower and control the gigantic physical forces generated around her. This is what ocean racing is all about now, and the sea and its mystical, sweeping, moody magnificence is relegated to a footnote. It is just a condition to be noted and handled properly, like the surface of a grand prix race-course in rain. nautique $^{8}$, et la course au large n'a plus rien à voir avec la voile. C'est du moins ainsi que l'envisage le navigateur britannique Pete Goss lorsqu'il retrace la première édition du BT Global Challenge ${ }^{9}$ auquel il a pris part : " the race had little to do with sailing -it was simply the medium through which the crew would realise the challenge of a lifetime » $(1998: 60)$.

La remarque de Pete Goss nous fournit une indication supplémentaire. Si les skippers se défendent d'écrire des livres sur la voile, ce n'est pas tant parce que la course au large nécessite la maîtrise de plusieurs domaines, que du fait de la représentation qu'ils cherchent à en donner. Pete Goss y voit avant tout une aventure : "This was an adventure in the true sense of the word» (1998: 64). Cette définition montre à quel point la limite se brouille entre texte spécialisé et fiction. Pour Christian Messenger, auteur de deux ouvrages sur le sport et la littérature, la fiction sur le sport n'est autre qu'une manière d'inscrire le matériau sportif dans des schémas narratifs traditionnels («ways in which conventional story patterns establish ways of dealing with sport material » (1981: xviii)). On serait alors tenté de déduire, a contrario, que le matériau sportif constitue le cœur même des écrits de Pete Goss ou d'Ellen MacArthur, qu'il informe leur récit sans se couler dans des schémas préexistants. Et pourtant, la remarque de Pete Goss sous-tend une mise en récit qui ne s'appuie pas sur la voile. C'est donc cette mise en récit qu'il importe d'examiner ici.

\section{La mise en récit d'un mythe}

14 L'introduction à Classic Sailing Stories suggère que l'ensemble des textes rassemblés dans le recueil, qu'ils soient écrits par des professionnels de la voile ou par des écrivains, s'appuie sur une représentation de la mer comme scène, une scène sur laquelle se déroule leurs récits : " the sea is a wonderful stage on which to unroll a dramatic narrative or introduce a heroic character» (McCarthy 2003 : ix).

La mer d'abord, donc, sur fond de tempête :

The Nan-Shan was being looted by the storm with a senseless, destructive fury: trysails torn out of the extra gaskets, double lashed awning blown away, bridge swept clean [...]

My main concern was the waves. A large and menacing sea had been whipped up from the southwest. [...] Individually they presented nothing more than one would expect - it was when they combined that they erupted into an unpredictable brute of tumbling water.

Steep, savage seas, with 45-knots blasts right on the Cape of NW Spain. Last night was the toughest I've spent on board. [...] The seas were just horrific, I couldn't stop her leaping over each wave and crashing down on to the next.

Dans tous les cas le milieu est hostile (« looted », « large and menacing » « unpredictable brute $»)$, sauvage («savage »), violent (« senseless, destructive fury» «horrific »). Pourtant, si la première citation provient de Typhoon de Joseph Conrad (1903: 44), la seconde est extraite de Close to the Wind de Pete Goss (1998: 270), et la troisième du livre de bord d'Ellen MacArthur lors du « Vendée Globe » $2001^{10}$. En personnifiant ainsi la mer le texte 
spécialisé rejoint la littérature. À l'instar du texte littéraire, il fait appel à l'imaginaire, et s'appuie sur une symbolique de l'océan déchaîné.

Dès lors, si la mer est le point de départ de la mise en récit, la dimension mythique en est le principe structurant. Il suffira pour s'en convaincre d'examiner les récits du passage du Cap Horn, cap mythique s'il en est. Ainsi pour le narrateur de White-Jacket, doubler le Cap Horn s'apparente à une descente aux enfers : "Was the descent of Orpheus, Ulysses, or Dante into Hell, one whit more hardy and sublime than the first navigator's weathering of that terrible Cape?» (in McCarthy 2003: 103). Avec ces mots, Melville ancre définitivement son récit dans le mythe. De manière plus inattendue sans doute, un siècle plus tard Melville encore et le capitaine Ahab sont devenus les mythes à l'aune desquels se mesure la quête des navigateurs en solitaire. Un article de Sports Illustrated à la mémoire d'Alain Colas compare ainsi l'aspect physique du navigateur à celui d'Ahab: « he walked with a limp the result of a sailing accident. The limp gave him an Ahab-like mystique " (Johnson 1979 : 121).

De fait les courses autour du monde en solitaire se prêtent à une exploitation mythique. La quatrième de couverture de Taking on the World annonce "A story of mythic shape ». Un homme / une femme seul(e) face à la furie des éléments déchaînés dans l'espace mythique qu'est le Grand Sud et dont la simple évocation suggère le danger ${ }^{11}$, et déjà le myth point. Les textes produits par les navigateurs présentent une étonnante proximité avec les textes littéraires. C'est cette similitude dans le schéma narratif que nous voudrions montrer par le biais de la mise en récit d'une tempête.

Les textes considérés sont d'une part Typhoon de Conrad et "MS found in a Bottle » d'Edgar Allen Poe, et d'autre part Taking on the World, Close to the Wind et un récit intitulé To the Great Southern Ocean écrit par un constructeur de navires à propos de sa propre navigation dans le Grand Sud. La mise en récit de la tempête comporte deux mouvements. Premier mouvement : le texte présente une série de signes annonciateurs de la tempête, à commencer par la chute de pression barométrique.

It would have been idyllic if it hadn't been for the barometric pressure, which was dropping fast. A fall of thirty-six millibars in twenty-four hours, and most of that had been in the last twelve. The forecast looked horrifying - the isobars on the weather chart were so close together that they seemed to merge into a solid black line. (Goss 1998 : 266)

The barometer was falling fast. (Robinson $1982: 97)$

The barometer was still dropping. (MacArthur $2003: 275$ )

Observing the steady fall of the barometer (Conrad $1903: 20$ )

[...] the barometer is rumbling down like anything. (Conrad $1903: 24)$

Barometer still falling. (Conrad $1903: 27)$

Viennent ensuite les nuages menaçants et noirs : « a dense black cloud became visible to the northward» (Conrad 1903: 26); "Sunset threatening, with low bank of clouds to N. and E. Sky clear overhead» (Conrad 1903: 26); «I observed a very singular, isolated cloud» (Poe 2002: $147)$; «the dark sky wasn't listening» (MacArthur 2003: 304 ${ }^{12}$ ) et une mer formée («she wallowed in the massive swell of the approaching storm » (MacArthur $2003: 315)$ ). C'est enfin le vent qui augmente graduellement jusqu'à déchaîner toute sa furie : " the wind was upon the increase » (Poe $2002: 150)$; « As night fell, both wind and sea were worse 》 (Robinson 1982 : 98). La description qu'en fait Pete Goss est particulièrement significative. L'augmentation constante du vent rythme son récit : «the wind [...] was rising at an alarming rate» (1998: $267)$; «The wind was still rising [...] still the storm hadn't settled - it continued to rise » (1998: 269) et il propose deux images caractéristiques. D'une part il offre la vision d'un vent hurlant cher à la fiction ${ }^{13}$ (« The wind was a screaming banshee lashing the ocean into a frenzy 
of spume and spray» [Goss $1998: 269]$ ), et d'autre part il souligne son aspect inquiétant par une référence aux enfers qui n'est pas sans évoquer la description de Melville dans White Jacket : « the wind was rising faster than I had ever experienced. I clambered back to the mast, put the third reef in and still the wind rose. Hell's teeth » (Goss $1998: 267)$.

Ensemble, ces signes visent d'abord à montrer le danger qui se profile à l'horizon ( I I had a deep sense of impending doom [...] I had experienced many severe blows over the years but this one, for some reason, held a heavy sense of foreboding. " [Goss 1998: 266]), ils cherchent ensuite à convaincre le lecteur qu'il s'agit d'une tempête unique, mythique, une tempête dont la force défie l'imagination. C'est en tout cas ce que professent les textes :

[I]t was to be the culminating storm experience of my life. Anything I had previously seen was child's play compared with what was in store for us during the next forty-eight hours (Robinson 1982 : 97).

still more terrific than any tempest I had before encountered. (Poe $2002: 150$ )

Le décor ainsi planté, reste alors à l'auteur à placer son/ses personnage(s), et c'est là la deuxième étape. Gaston Bachelard voit dans «l'eau violente [...] un schème de courage " (1991 : 226). Et c'est bien de cela qu'il s'agit, mettre en scène le courage de l'homme face à la furie des éléments. La quatrième de couverture de Close to the Wind résume admirablement ce dessein : "The story of a brave man; a man who turned into the teeth of a hurricane to save the life of a fellow competitor " (in The Spectator). Sur le même mode, la quatrième de couverture de Taking on the World souligne les qualités héroïques d'Ellen MacArthur : "The first true heroine of the twenty-first century " (in The Observer). En effet, si ces deux ouvrages sont des textes spécialisés, ce sont aussi les autobiographies des skippers. À ce titre, ils se donnent à lire comme une mise en scène de leur auteur. L'océan est alors le miroir qui renvoie et révèle tout à la fois l'image de leur héroïsme. «I ventured on deck and the fight began " (Goss 1998 : 273). Dans la lutte contre les éléments, l'exploit sportif prend des allures d'épopée ${ }^{14}$.

The sport hero in American fiction has been a special figure, a man apart from mass man. [....] Because of peculiar skills, he is lionized and given heroic status.

(Messenger $1981: 1$ ) Pour mieux projeter l'exploit, il convient d'être seul. Les navigateurs ne s'y seront pas trompés. Des titres en forme de programme, tel Alone against the Atlantic (Spiess : 1981), aux remarques qui balisent leur textes («one man, one boat against the elements» (Goss 1998 : 1) ; « except I was on my own » (Goss 1998: 266), les skippers mettent en scène la solitude.

Relater une course autour du monde à la voile revient certes à ancrer un texte dans le milieu de la voile, mais aussi à construire un récit. Or, dès lors que la mise en récit des textes spécialisés obéit à la même logique que celle des textes littéraires, se pose aussi la question de la langue employée. Et avec elle, celle de savoir s'il est possible de définir un style des autobiographies nautiques.

\section{Questions de style}

«For better or for worse there is a language of sailing, " affirme Dennis Conner (1994: 8). Quand ce spécialiste, quadruple vainqueur de la coupe de l'America, s'adresse au néophyte il commence par définir la terminologie propre à la voile "We start with 
terminology " (1994: 8). Sur le même mode, un article de The Guardian visant à initier les lecteurs à la voile se conclut, sous le titre de "Sailing Talk", par un petit glossaire des termes employés (5 août 2000).

De fait si les navigateurs se défendent d'écrire des livres sur la voile ( I I have not tried to write a sailing book, nor a book about the Vendée Globe » MacArthur 2003 : xix), c'est en partie parce que le grand public partage la vision de James Thurber sur la terminologie de voile, à savoir qu'elle pourrait tout aussi bien être du Sanscrit :

[...] the rigging of the modern sailing ship has become complicated beyond all necessity. If you want proof of this, you only have to look up the word rigging in the Encyclopaedia Britannica. You will find a drawing of a full-rigged modern ship and under it an explanation of its various spars, masts, sails, etc. [...] The tendency of the average landlubber who studies this diagram for five minutes is to turn to Sanscrit in the encyclopaedia and study up on that instead. (1982 : 323-324)

Afin d'atteindre le plus grand nombre de lecteurs possible, le professionnel de la voile revendique alors la transparence de la terminologie employée. Son texte se lit comme un roman et n'a pas besoin d'être décrypté, ou du moins telle est l'idée qu'il cherche à projeter.

Cherchant à se rendre plus accessible, Ellen MacArthur définit son objet par le biais d'un glossaire: «I have assumed basic sailing knowledge in the text, but for those of you who have not yet experienced the feeling of water beneath you, there is a glossary at the back» (2003:xviii).

Mais ce glossaire a également une autre fonction, celle d'éliminer toute polysémie. Chaque terme renvoie à un signifiant unique qui fait consensus du fait même de sa définition. P. Lerat (1995: 91) cite Guilbert à ce propos: «Le trait spécifique de la terminologie technique est la recherche de la monosémie par opposition à la polysémie généralisée des termes du lexique général de la langue ». C'est sans doute là également la différence essentielle avec la littérature. La littérature laisse résonner les mots et ouvre le texte sur de multiples lectures, alors qu'à l'inverse le texte spécialisé vise un sens univoque. Il suffit pour s'en convaincre d'examiner deux textes : d'une part un extrait du livre de bord d'Ellen MacArthur et, d'autre part, une référence à un autre livre de bord celui du navire de Typhoon:

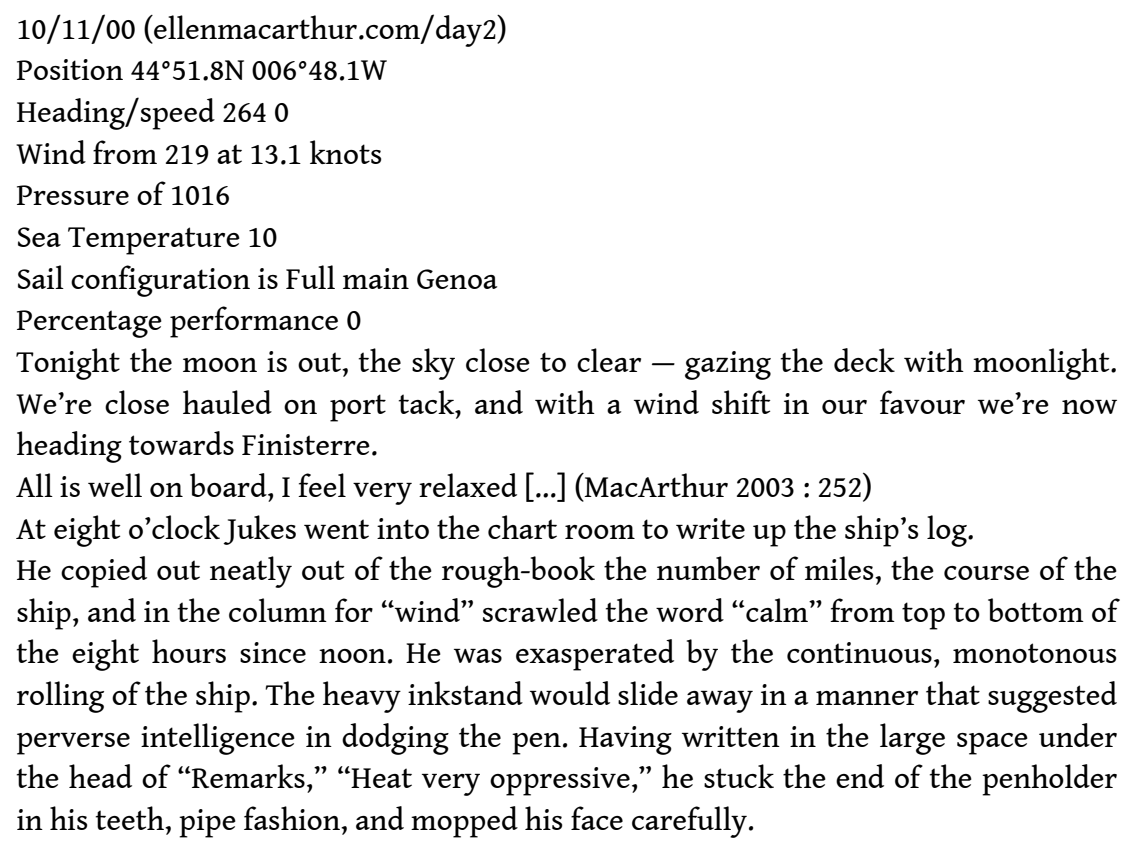
rolling of the ship. The heavy inkstand would slide away in a manner that suggested perverse intelligence in dodging the pen. Having written in the large space under the head of "Remarks," "Heat very oppressive," he stuck the end of the penholder in his teeth, pipe fashion, and mopped his face carefully. 
"Ship rolling heavily in a high cross swell," he began again, and commented to himself, "Heavily is no word for it." Then he wrote:

"Sunset threatening, with low bank of clouds to N. and E. Sky clear overhead."

(Conrad $1903: 26$ )

MacArthur et Conrad mentionnent la distance parcourue, le cap et la force du vent, pourtant la première impression est d'être confronté d'une part à une liste brute et d'autre part à sa mise en forme textuelle. Le texte de Conrad ne serait alors rien de plus que la mise en récit du livre de bord du Nan-Shan, le décodage d'une procédure technique. Pourtant, si l'on s'en tient à cette analyse, il est difficile de rendre compte de manière adéquate de Taking on the World. Mêlant des extraits de livre de bord à des passages narrés, Mac Arthur propose un texte hybride où alternent texte codifié et narration à la première personne ${ }^{15}$. La différence est ailleurs. Pour ce qui est du vent, «calm» s'oppose à «13.1 knots ». Si le premier laisse la place à l'interprétation, le second propose une lecture univoque. La logique qui prévaut ici est la même que pour l'inclusion du glossaire, le texte spécialisé vise la monosémie.

De manière plus évidente encore pour ce qui est du cap, là où Conrad relate les actions effectuées et mentionne le cap sans le livrer au lecteur (« copied out neatly out of the roughbook [...] the course of the ship »), MacArthur transmet précisément la position du bateau (« Position $\left.44^{\circ} 51.8 \mathrm{~N} 006^{\circ} 48.1 \mathrm{~W} »\right)$. Le flou laissé par la phrase de Conrad interdit au lecteur de placer le navire sur une carte. Dépourvu de repères spatiaux stricts, son sort est alors de l'ordre de la métaphore. À l'inverse les indications précises de Mac Arthur sur la force du vent et le cap ancrent le récit dans la logique de course. Elle nous livre sans les modifier les éléments, consignés dans le livre de bord, qui lui ont permis de déterminer ses options tactiques. Ce choix n'est pas sans importance. Ailleurs elle fera le choix inverse d'occulter certaines informations : «I remembered that at one point we were sailing with a fair amount of wind with three reefs in. We were under-canvased" (183). On peut donc émettre l'hypothèse que l'extrait de Taking on the World nous plonge dans une logique de course, alors qu'à l'inverse, l'extrait de Typhoon invite à une lecture poétique. C'est du reste ainsi qu'il faut comprendre les commentaires que Conrad insinue entre les indications techniques. Ses remarques sur l'encrier et sur le stylo sont autant d'indications sur l'état d'esprit du personnage.

La dernière phrase de l'extrait mérite qu'on s'y arrête : «Sunset threatening, with low bank of clouds to N. and E. Sky clear overhead ». Isolée du reste du texte, la phrase ne se distingue d'un écrit spécialisé ni au niveau du lexique employé, ni au niveau de son style. On serait peut-être même plus enclin à la considérer comme un texte spécialisé que la phrase de MacArthur qui évoque l'état du ciel : "Tonight the moon is out, the sky close to clear - gazing the deck with moonlight. » Ce qui caractérise le texte de Conrard par rapport à celui de MacArthur, ce n'est donc ni la technicité des termes employés, ni la structure de phrases isolées, mais son agencement. L'ensemble du texte tend vers la remarque finale en forme d'écho au titre « And then he closed resolutely his entries: 'Every appearance of a typhoon coming on.' » (Conrad 1903 : 27). Au final, le texte s'appuie sur une organisation poétique.

À l'inverse, l'architecture du texte spécialisé obéit à une logique professionnelle. Dans la première partie de l'extrait de Taking on the World, l'ordre des termes est prédéfini par l'usage et est donc strictement identique d'un skipper à l'autre. Le livre de bord doit comporter un certain nombre de rubriques, rubriques qui chacune appellent un nombre limité de possibles. À "Sail configuration" répond ainsi un nombre précis de combinaisons, où "full main", " $1^{\text {st }}$ reef ", " $2^{\text {nd }}$ reef " et « $3^{\text {rd }}$ reef " peut être associé à " 
solent", "genoa", «code 5 » et "spinnaker». MacArthur se conforme ici à l'usage professionnel usuel et l'architecture interne du passage est de l'ordre du code. En revanche, la seconde partie de l'extrait et l'agencement des extraits de carnet de bord dans la narration n'est plus de l'ordre de la procédure technique. Et c'est là tout son intérêt. MacArthur aura voulu nous donner à voir sa logique de course, ses options tactiques propres. Une course ne se gagne pas en reproduisant des procédures techniques attestées mais par des options tactiques personnelles. C'est bien cela que reflète le texte, la part du personnel dans le technique.

\section{Conclusion}

Lorsque le professionnel du sport emprunte à la littérature ses schémas narratifs, et inversement lorsque l'écrivain emprunte au sportif sa terminologie, les limites entre langue spécialisée et littérature s'estompent. Loin de compromettre l'étude de la langue spécialisée, ce brouillage permet au contraire de mieux la définir. Il interdit de réduire le milieu professionnel à une pure technicité, de limiter l'étude de la langue à celle des caractéristiques de sa terminologie. Dans le cas d'une course autour du monde en solitaire, l'aventure, la quête, et la compétition sont partie intégrante du sport au même titre que la maîtrise technique du navire et du milieu dans lequel il évolue. Ils influent donc sur la langue de la voile et sur les écrits spécialisés. En montrant l'influence du skipper sur le texte spécialisé, cette étude aura surtout voulu envisager la langue spécialisée comme un milieu mouvant. Si le texte spécialisé est codifié, il n'est pas figé.

\section{BIBLIOGRAPHIE}

\section{Références du corpus}

Conner, Dennis. 1994. Learn to Sail: A Beginner's Guide to the Art, Equipment and Language of Sailing on a Lake or Ocean. New York: St Martin's Press.

Conrad, Joseph. 1903. Typhoon. New York : Doubleday, Doran and Company, Inc.

Goss, Pete. 1998. Close to the Wind. London : Headline Book Publishing.

Johnson, William Oscar. 1982. «Alain Colas : A legend lost at sea » Sports Illustrated Jan 8, 1979. In Bartlett, M. \& J. A.Fishman (dir.), The Sailing Book. New York : Arbor House, 121-131.

Knecht, Bruce G. 2002. The Proving Ground : the Story of the Disastrous Sydney to Hobart Boat Race 1998. Londres : Harper Collins Publishers.

Mac Arthur, Ellen. 2001. « Alone, alone on a wide, wide sea ». The Observer. (11 février)

MacArthur, Ellen. 2003 (2002). Taking on the World. Londres : Penguin Books Ltd.

McCarthy, Tom (dir.). 2003. Classic Sailing Stories: Fifteen Incredible Tales of the Sea. Guilford, Conn. : The Lyons Press. 
Poe, Edgar Allan. 2003 [1831]. « MS found in a bottle » In McCarthy, Tom (dir.) Classic Sailing Stories : Fifteen Incredible Tales of the Sea. Guilford, Conn. : The Lyons Press.

Robinson, William A. 1982. « The Ultimate Storm » in Bartlett, Michael \& Joanne A.Fishman (dir.), The Sailing Book. New York : Arbor House, 97-105.

Spiess, Gerry. 1981. Alone Against the Atlantic. Minneapolis : Control Data Publishing.

\section{Site Internet}

<http://www.ellenmacarthur.com>.

\section{Références}

Albouy, Pierre. 1969. Mythes et mythologies dans la littérature française. Paris : Armand Colin. Atherton, John. 1988. « Sport et culture aux États-Unis ». In Atherton, John \& Richard Sibley (dir.), Le sport en Grande-Bretagne et aux États-Unis : faits, signes et métaphores. Nancy : Presses universitaires de Nancy, 9-15.

Augustin, Catherine. 1988. «Quelques remarques sur la presse anglo-saxonne des sports nautiques : l'exemple de Surfer et Windsurf ». In Atherton, John \& Richard Sibley (dir.), Le Sport en Grande-Bretagne et aux États-Unis : faits, signes et métaphores. Nancy : Presses universitaires de Nancy, 73-81.

Bachelard, Gaston. 1991 [1942]. L'Eau et les rêves : essai sur l'imagination de la matière. Paris : José Corti.

Chareyre-Méjean, Alain. 1992. « L’Annulation par la tempête ». In Europe :Joseph Conrad 758-759, juin-juillet, 99-110.

Chenetier, Marc. 1988. « Football et baseball chez Robert Coover : ontologie, rituel et histoire ». In Atherton, John \& Richard Sibley (dir.), Le sport en Grande-Bretagne et aux États-Unis : faits, signes et métaphores. Nancy : Presses universitaires de Nancy, 93-102.

D'Arcy, Julian. 2003. « Sport Literature : The ball in the academic court ». The European Messenger 12/1, 47-53.

Jacquin, Bernard. 1988. «Le Sport comme célébration, contestation ou liquidation d'un ordre social dans le roman anglais du XX $\mathrm{XX}^{\mathrm{e}}$ siècle ». In Atherton, John \& Richard Sibley (dir.), Le Sport en Grande-Bretagne et aux États-Unis : faits, signes et métaphores. Nancy : Presses universitaires de Nancy, 83-92.

Lerat, Pierre. 1995. Les Langues spécialisées. Paris : Presses universitaires de France.

Messenger, Christian K. 1981. Sport and the Spirit of Play in American Fiction: Hawthorne to Faulkner. New York : Columbia University Press.

Messenger, Christian K. 1990. Sport and the Spirit of Play in Contemporary American Fiction. New York : Columbia University Press.

Nichols, Peter. 2002. «Book Review » The Guardian 14 novembre. <http://

www.ellenmacarthur.com>.

Resche, Catherine. 2001. «Réflexions sur la frontière entre langue générale et langue spécialisée ». In Mémet, Monique \& Michel Petit (dir.), L'anglais de spécialité en France. Bordeaux : GERAS éditeur, 37-45.

Thurber, James. 1982. « The story of sailing ». In M. Bartlett \& J. A. Fishman (dir.), The Sailing Book. New York : Arbor House, 323-325. 
The Guardian. 5 août 2000. « Sailing Talk ».

Sports Illustrated. 16 décembre 2002.

\section{NOTES}

1. Même si Sports Illustrated affirme être un magazine généraliste sur le sport, la grande majorité des articles sont consacrés à quatre sports d'équipe: le football, le baseball, le hockey et le basketball.

2. Comme le souligne Marc Chenetier, « le roman de baseball aux États-Unis est un sous-genre à l'égal du policier ou du western novel $(1988$ : 97). Reconnus comme sous-genres littéraires, les romans de football et de baseball le sont aussi comme objets d'étude. En témoigne la création de la Sports Literature Association (East Tennessee State University) et d'une revue qui lui est associée, consacrée au sport dans la littérature, Aethlon: The Journal of Sport Literature.

3. Le discours littéraire sur le sport écarte d'emblée la pertinence documentaire des œuvres: «On donnera donc aux propos qu'ils tiennent sur le sport un sens métaphorique, sans trop se soucier de la valeur documentaire de leur propos. Leur véracité sera de l'ordre du symbole, non pas de l'ordre de la description » (Jacquin $1988: 84$ ).

4. Interview avec Harry Stein («Baseball on Their Minds », New York Times Book Review, June 1, 1986) In Marc Chenetier (1988 : 99).

5. « An interview »In Christian Messenger (1985:335).

6. «A sailing masterpiece » The Proving Ground, quatrième de couverture.

7. Ellen MacArthur est un membre reconnu du milieu de la voile. Elle a entre autres terminé deuxième du «Vendée Globe » en 2001, et gagné la « Route du Rhum » en 2003. De plus, comme elle le précise dans son introduction, Taking on the World s'adresse à un public averti.

8. Il serait utile d'étudier l'influence des emprunts entre disciplines sur la langue de la voile, mais cette étude dépasse le cadre de notre propos.

9. Le BT Global Challenge est une course autour du monde à l'envers et en équipage sur des voiliers identiques. La première édition de cette course, dont il est question ici, se nommait le British Steel Challenge et a eu lieu en 1992.

10. Cette transcription exacte de son livre de bord a été publiée dans The Observer (11 février 2001).

11. "The Southern Ocean represents the consummate challenge for any long-distance sailor [...]. As they push further and further south towards the Horn, they will face storm after storm. [...] It is the ultimate test of man and vessel across the last great wilderness. » (Goss $1998: 1$ )

12. La même thématique se décline aussi dans une version technologique par le biais des images satellite des nuages: "he saw a satellite generated image of a cyclone-like cloud pattern " (Knetcht $2002: 3)$.

13. On peut se reporter à ce propos à l'analyse de Pierre Albouy (1969: 242-243).

14. La presse a recours aux mêmes procédés narratifs comme en témoigne un article de Sports Illustrated intitulé "Alain Colas: A legend lost at sea ": " a man whose life contained the stuff of legend. » « And even among these extraordinary few, Colas stood apart » (Johnson 1982 : 121).

15. Les extraits du livre de bord tels qu'ils apparaissent dans Taking on the World n'ont pas été réécrits. Ils sont la transcription exacte du livre de bord de Kingfisher: "transcribed logs, correspondence, and more recent e-mails sent from the ocean in their original form " (MacArthur 2003: xviii). C'est nous qui soulignons. 


\section{RÉSUMÉS}

L'objet de cet article est d'interroger l'espace d'intersection où la langue de spécialité rejoint la littérature. Puisant son inspiration dans la voile, la littérature en revendique une exploitation métaphorique. À l'inverse, les professionnels de la voile s'arrogent l'unique maîtrise de l'expertise technique. Rien ne semble donc plus éloigné que littérature et langue de spécialité. Pourtant, dès lors que l'on examine les textes, les limites se brouillent. Les récits des courses au large en solitaire d'Ellen Mac Arthur (Taking on the World) et de Pete Goss (Close to the Wind) rejoignent Melville et Conrad dans leur exploitation de la mer comme espace mythique. C'est ce que cette étude montre dans un premier temps en examinant comment la fonction mythique influe sur la structure des textes spécialisés. L'article s'attache ensuite à savoir ce qui différencie et rapproche tout à la fois « la langue de la voile » et la langue littéraire quand celle-ci traite de la voile. Au travers de Taking on the World et de Typhoon l'auteur montre que c'est moins l'emploi de termes techniques qui différencie le texte spécialisé du texte littéraire, que l'influence de la visée poétique ou professionnelle sur la structure globale des textes.

This article aims at examining the intersection between specialized language and literature. Drawing its inspiration from sailing, literature claims a purely metaphorical exploitation of its material. Conversely, sailing professionals profess to be the sole capable of technical expertise. Nothing seems more distinct than literature and specialized language. Yet as soon as one examines the texts, the limits tend to blur. Sailing narratives of round the world single-handed races such as Ellen Mac Arthur's Taking on the World and Pete Goss's Close to the Wind follow the same pattern as the writings of Melville and Conrad through their mythic exploitation of the sea. This study aims first at showing how this mythic function influences the structure of specialized texts. It then concentrates on what distinguishes as well as connects "the language of sailing" from the literary language dealing with sailing. Through the examples of Taking on the World and Typhoon, the purpose of this study is to show that the difference between a specialized text and a literary text depends less on the use of technical terms than on the way the poetic or professional intent of a text influences its global structure.

\section{INDEX}

Mots-clés : autobiographie, Conrad (Joseph), langue de la voile, MacArthur (Ellen), structure narrative

Keywords : Conrad (Joseph), language of sailing, MacArthur (Ellen), narrative structure, autobiography

\section{AUTEUR}

GWEN LE COR 